\title{
Myths and Facts about COVID-19: The Pandemic
}

\author{
Jaya Pradha Dhandapani ${ }^{1}$, Dhivagar Subburayan ${ }^{2}$
}

\begin{abstract}
The corona virus disease 2019 (COVID-19) in India is a part of the worldwide pandemic caused by severe acute respiratory syndrome corona virus 2. ${ }^{1}$ Slowly, the pandemic spread to various states including the union territory of Puducherry. ${ }^{2}$ The first case was recorded in Puducherry on March 17, 2020. Currently, a significant high-level prevalence of COVID-19 has been identified in almost all over Puducherry, which reached approximately 30,000 cases till date, and it takes a challenging lead in treating corona-positive patients in the pandemic situation. ${ }^{5}$ It reflects there is miscegenation about the novel coronavirus in the society. There are lots of myths and facts that muddle in the minds of positive COVID-19 patients. ${ }^{8}$ Hence, this article focuses on the myths and facts reflecting the level of cognition and also creates a general awareness about COVID-19 among the general public. ${ }^{10}$

Keywords: COVID-19, Disease, Facts, Myths, Spreading.

Pondicherry Journal of Nursing (2021): 10.5005/jp-journals-10084-13101
\end{abstract}

\section{INTRODUCTION}

Corona virus disease 2019 (COVID-19) is a deadly virus, which arises in high virulence all over the world. Miscegenation of information to the public will defeat the right information. ${ }^{1}$ They can muddle in their minds about COVID-19 and create stigma over together. ${ }^{2}$ Here, we focus on the various myths and facts about the deadly virus, give a crystal clear idea about COVID-19, and reduce the spread of the novel coronavirus in the world. ${ }^{3}$

\section{Myths about COVID-19}

There is no scientific research evidence about the myths on COVID-19, here such an imbecile attitude can create a superstitious belief among the current generation, which are as follows: ${ }^{3}$

- COVID-19 is transmitted in the areas with high humid climates and hot climates.

- Can sprinkle alcohol or chlorine all over the body to destroy COVID-19. ${ }^{4}$

- Hot water bath is effective in reducing the risk of COVID-19.

- Vaccines against pneumonia will be the protective measure against COVID-19 virus. $^{5}$

- Regular rinsing of your nose and mouth with saline solution assures to prevent the virus.

- COVID-19 virus only affects the elderly and persons with comorbidity.

- The positive COVID-19 patient might die.

- Eating garlic will prevent the infection.

- AYUSH is the best medicine for COVID-19 compared to allopathic medicines.

- Vitamin C will prevent the deadly virus.

- Only wearing a mask prevents COVID-19 virus.

- Eating herbal plants can cure COVID-19.

- Dried ginger tea is the herbal treatment for COVID-19.

- Eating meat can cause coronavirus.

- Hold your breath for 10 seconds is the health practice to confirm the absence of COVID-19.

- Taking alcohol can prevent COVID-19.
${ }^{1}$ Department of Obstetrics and Gynecology Nursing, Kasturba Gandhi Nursing College, Sri Balaji Vidyapeeth, Puducherry, India

${ }^{2}$ Department of Psychiatric Nursing, Kasturba Gandhi Nursing College, Sri Balaji Vidyapeeth, Puducherry, India

Corresponding Author: Jaya P Dhandapani, Department of Obstetrics and Gynecology Nursing, Kasturba Gandhi Nursing College, Sri Balaji Vidyapeeth, Puducherry, India, Phone: +91 7639126403, e-mail: J.pradhaa17@gmail.com

How to cite this article: Dhandapani JP, Subburayan D. Myths and Facts about COVID-19: The Pandemic. Pon J Nurs 2021;14(2):46-47.

Source of support: Nil

Conflict of interest: None

\section{Facts about COVID-19}

- There is no evidence of clinical benefits of hydroxychloroquine to treating COVID-19.

- The COVID-19 is caused by a virus, not by bacteria.

- The long period of using medical masks when wore properly would not cause carbon dioxide intoxication or deficiency of oxygen. $^{5}$

- Most people who get COVID-19 recover from general treatment.

- Risk of comorbidity with positive polymerase chain reaction testing may reflect a poor prognosis.

- Intake of alcohol would not protect against coronavirus and can be fatal.

- Thermal scanners cannot detect COVID-19.

- Sprinkle and usage of bleach or any another sterilizations into our body do not protect against COVID-19 and can be more severe.

- Consuming methanol, ethanol, or bleach would not prevent or cure coronavirus and can be severely threatening.

- 5 G mobile networks do not spread COVID-19.

- Exposing yourself to the sun or temperatures higher than $25^{\circ} \mathrm{C}$ does not protect you from COVID-19. ${ }^{6}$

- Freezing weather and blizzard would not kill the COVID-19 virus.

(0) The Author(s). 2021 Open Access This article is distributed under the terms of the Creative Commons Attribution 4.0 International License (https:// creativecommons.org/licenses/by-nc/4.0/), which permits unrestricted use, distribution, and non-commercial reproduction in any medium, provided you give appropriate credit to the original author(s) and the source, provide a link to the Creative Commons license, and indicate if changes were made. The Creative Commons Public Domain Dedication waiver (http://creativecommons.org/publicdomain/zero/1.0/) applies to the data made available in this article, unless otherwise stated. 
- Bathing in hot water would not be preventing COVID-19.

- Mosquitoes and other biting insects do not spread COVID-19 virus. $^{6}$

- Hand dryers are not essential in destroying the COVID-19 virus.

- Ultraviolet lamps are not used to sanitize hands or other areas of skin.

- Vaccines against pneumonia do not protect against the COVID-19 virus.

- Washing nose with saline does not prevent COVID-19 virus. ${ }^{7}$

- Taking garlic would not prevent COVID-19.

- People of all ages have a chance to be infected by the COVID-19 virus. $^{7}$

- Antibiotics do not prevent or cure COVID-19.

- There are no sort of medicines that can prevent or cure COVID-19.

\section{Conclusion}

Coronavirus has grappled the world day by day. ${ }^{8}$ With no preventive measure or cure in sight, a lot of misinformation is available on the media and it muddles between the general public; it can be hard to actually separate the fact from the fiction. ${ }^{9}$ We must find a lot of myths and hoax messages related to COVID-19 infection. The people should trust the recognized governmental organization about the facts on COVID-19 to reduce the anxiety during the pandemic situation. ${ }^{10}$

\section{References}

1. Waterson J. Influencers among 'key distributors' of corona virus misinformation; 2020.

2. Kampf G, Todt D, Pfaender S, Steinmann E. Persistence of corona viruses on inanimate surfaces and their inactivation with biocidal agents. J Hosp Infect 2020;104(3):P246-P251. DOI: 10.1016/ J.Jhin.2020.01.022.

3. Fehr AR, Perlman S. Corona viruses: an overview of their replication and pathogenesis. Methods Mol Biol 2015;1282:1-23. DOI: 10.1007/978-1-4939-2438-7_1.

4. Bursztyn L, Rao A, Roth C, Yanagizawa-Drott D. Misinformation during a pandemic. Becker Friedman Institute for Economics at The University of Chicago; 2020 [Retrieved April 21, 2020].

5. Brennen JS, Simon F, Howard PN, Nielsen RK. Types, sources, and claims of COVID-19 misinformation. Reuters Institute; 2020 [Retrieved April 21, 2020].

6. Nebehay S, Shields M. "Fatal mistake" for countries to assume they won't get corona virus - who chief. Reuters; 2020 [Accessed March 6, 2020].

7. Carbone M, Green JB, Bucci EM, Lednicky JA. Corona viruses: facts, myths, and hypotheses. J Thorac Oncol 2020;15(5):675-678. DOI: 10.1016/J.Jtho.2020.02.024.

8. Kassam N. Disinformation and corona virus. The interpreter. Lowy Institute; 2020.

9. Lytvynenko J. Here's a running list of disinformation spreading about the corona virus. Buzz Feed News [Archived February 6, 2020; Retrieved February 8, 2020].

10. Berman R. COVID-19: study highlights sources of misinformation. Medical News Today; 2020. 